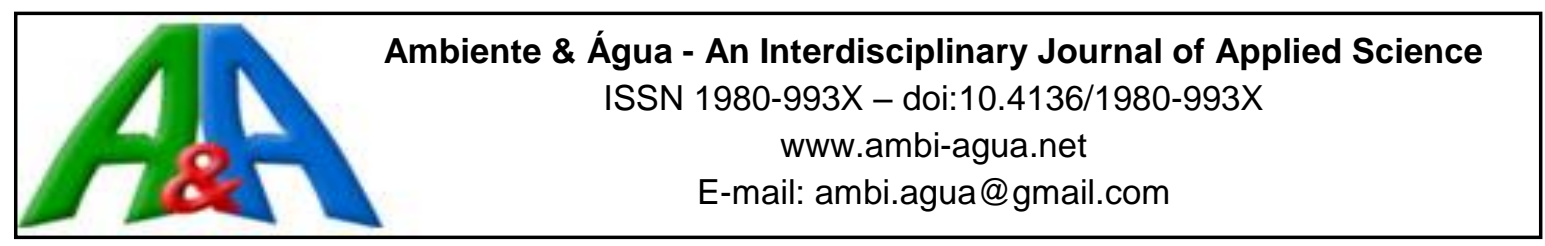

\title{
Analysis of the effect of impermeability of urban soils on the infiltration of rainwater in the city of Recife, $\mathrm{PE}$
}

\author{
ARTICLES doi:10.4136/ambi-agua.2386
}

Received: 25 Feb. 2019; Accepted: 10 Jun. 2019

\author{
Marco Aurelio Calixto Ribeiro de Holanda*iD; Willames de Albuquerque Soares \\ Universidade de Pernambuco (UPE), Recife, PE, Brasil \\ Escola Politécnica de Pernambuco (POLI). \\ E-mail: holandamacr@yahoo.com.br,was@poli.br \\ *Corresponding author
}

\begin{abstract}
The process of urbanization interferes in the elements of the hydrological cycle, altering the infiltration, flow, and evaporation of rainwater. Several methods and tests exist for analyzing this hydrological cycle that aim to hydrodynamically characterize the soil of a locality. However, the collection and field trials can be expensive and time consuming. Because of these high costs, it is important to look for methods that save time and money. One such method is to perform simulations of water flow in the soil, using computational models such as Hydrus 1-D, in order to explain the water balance of a region. The results of these simulations showed that $355.18 \mathrm{~mm} . \mathrm{m}^{-2}$ of the total $385.02 \mathrm{~mm} . \mathrm{m}^{-2}$ of precipitation was able to infiltrate, indicating that the soil of the region has a high infiltration capacity, due to its high sand content. However, of the $228,000 \mathrm{~m}^{2}$ studied, only $38,760 \mathrm{~m}^{2}$ are unpaved soil. This shows that the soil at the location studied would be able to infiltrate most rainwater without the occurrence of flooding, if more than only $17 \%$ of the land area were permeable soil. This conclusion can be extrapolated to other areas surrounding this neighborhood and to other large urban centers, which have similar characteristics.
\end{abstract}

Keywords: Hydrus-1D, infiltrability, soil hydrodynamics.

\section{Análise do efeito da impermeabilização dos solos urbanos na infiltração de água pluvial na cidade de Recife-PE}

\section{RESUMO}

O processo de urbanização interfere nos elementos do ciclo hidrológico, alterando as características de infiltração, escoamento e evaporação da água oriunda da chuva. Para analisar este ciclo hidrológico há diversos métodos e ensaios que visam caracterizar hidrodinamicamente o solo de uma localidade. Entretanto, a realização de coletas e ensaios de campo são onerosos e morosos. Por conta destes altos custos, é importante buscar métodos que visem economizar tempo e dinheiro. Uma das maneiras, é realizar simulações do fluxo de água no solo, mediante o uso de modelos computacionais como o Hydrus 1-D, afim de explicar o balanço hídrico de uma região. Os resultados dessas simulações apontaram que dos $385.02 \mathrm{~mm}$ que precipitaram $355.18 \mathrm{~mm}$ infiltraram, mostrando que o solo da região possui uma grande capacidade de infiltração, o qual é composto majoritariamente por areia, entretanto, dos 
$228000 \mathrm{~m}^{2}$ estudados apenas $38760 \mathrm{~m}^{2}$ são de solo não pavimentado. Estes resultados mostram que o solo do local estudado seria capaz de infiltrar a água pluvial sem gerar alagamentos, caso não houvesse apenas $17 \%$ de solo não impermeabilizado. Além disso, esta conclusão pode ser extrapolada para as áreas que circundam este bairro e também para grandes centros urbanos, uma vez que eles possuem características semelhantes.

Palavras-chave: dinâmica da água no solo, Hydrus-1D, infiltrabilidade.

\section{INTRODUCTION}

Water is a natural resource of great relevance to anthropic activities in many areas. Its cycle is indispensable for the maintenance of the passive balance between urbanization and nature. The processes that make up the hydrological cycle, from infiltration to evapotranspiration to surface runoff, are dependent on the physical environment in which they are found (Tucci, 2007).

The urbanization process interferes with the elements of this hydrological cycle, modifying the environment through deforestation, degradation of natural areas, as well as other damages, such as impermeabilization of the soil, lack of an ideal urban drainage system, and pollution of the catchment and outflow network, all related to the growth of population (Corte, 2015).

Soil is a vital part of the environment. It influences the distribution of plant species and provides a habitat for a large number of organisms. It also functions as a filtration system between the atmosphere and the earth for surface water and chemicals. Soil is relevant to the destiny of society because of the goods, resources, and services that it provides to humanity (Soares, 2018).

The water inside the soil exerts forces that influence the state of tension of the soil, modifying its stability, among other pertinent edaphic attributes (Carvalho and Almeida, 2018). Moisture has a great influence on the physical behavior of the soil, especially with regard to the dynamics of water caused by external agents, such as rain. The greatest interactions occur in the topmost surface layers of the soil, where the highest water flow rates can be observed in two directions: descending (infiltration) and ascending (evaporation). Beyond these vertical movements of water, the accumulation of water on the surface can also occur when the precipitation rate is greater than the infiltration rate. When this happens, water will pool on the surface of the soil, possibly giving rise to surface runoff (Simůnek et al., 2013).

With urbanization, the consequent impermeabilization of the soil is a current and recurrent problem for aquifers and groundwater sources, especially in large urban centers, because the water supply comes from water that infiltrates from the surface into the lower layers of the soil. There is great variability in the amount of time it takes for this process to occur completely, from days up to years (Cavalcanti, 2013).

According to Tucci (2004), a large urban concentration is considered to be a problem that favors flooding because of the improper use of land and the occupation of space, as well as through the insufficient management of urban drainage. Lack of planning and undue land occupation in the metropolitan area of Recife, together with high rainfall levels and variations in high tide, cause numerous floods.

There are many methods and tests that can be used to hydrodynamically characterize the soil of a locality. Because field experiments and laboratories are expensive and timeconsuming, many researchers have used numerical and analytical methods that make it possible to characterize the soil with great efficiency (Martinez and Silva, 2010). Zeng et al. (2018) used software to simulate a variety of possible events, obtaining results that match closely with reality.

Researchers like Mujovo (2014) have used computational models, such as Hydrus-1D, to 
perform hydrodynamic characterization of soils in urban areas, in order to control urban drainage by simulating infiltration trench models. This model has proven to be an excellent tool in decision making for drainage control techniques.

The use of these computational models has already become a reality in the scientific environment, because beyond modeling and predicting the objects of study accurately and precisely, they also save time and financial resources. This study estimated the water infiltration capacity of the soil using computational modeling of water flow by computational models such as Hydrus 1-D in a central and representative region of the city of Recife, the Madalena district, with data parameters of precipitation, insolation, and soil granulometry.

\section{MATERIALS AND METHODS}

The study area, in the Madalena neighborhood, is one of the main corridors connecting downtown Recife with the suburbs, through which can be accessed places such as the Federal University of Pernambuco and the Integrated Passenger Terminal. In addition, it contains several large shopping areas, hosts the Benfica campus of the University of Pernambuco and the Adelmar da Costa Carvalho football stadium. It also contains many residential units and some government offices.

The area shown in Figure 1, having approximately $228,000 \mathrm{~m}^{2}$, indicates the location studied containing the points where 27 samples were collected. In areas with natural soil cover, which make up $17 \%$ of the total study area, samples were collected for the purpose of laboratory tests. The points chosen were public squares, partially wooded and without large impermeabilized areas, as well as grassy areas with few trees making up part of the property of a local supermarket.

Much of this section of the Capibaribe River has a retaining wall separating the mangroves from the roads that border it. This wall was constructed to prevent the roads from being affected by the water during periods of high tide. Therefore, the physical properties of the superficial layers of the unpaved soil along the riverside are not influenced by the transport of fluvial sediments.

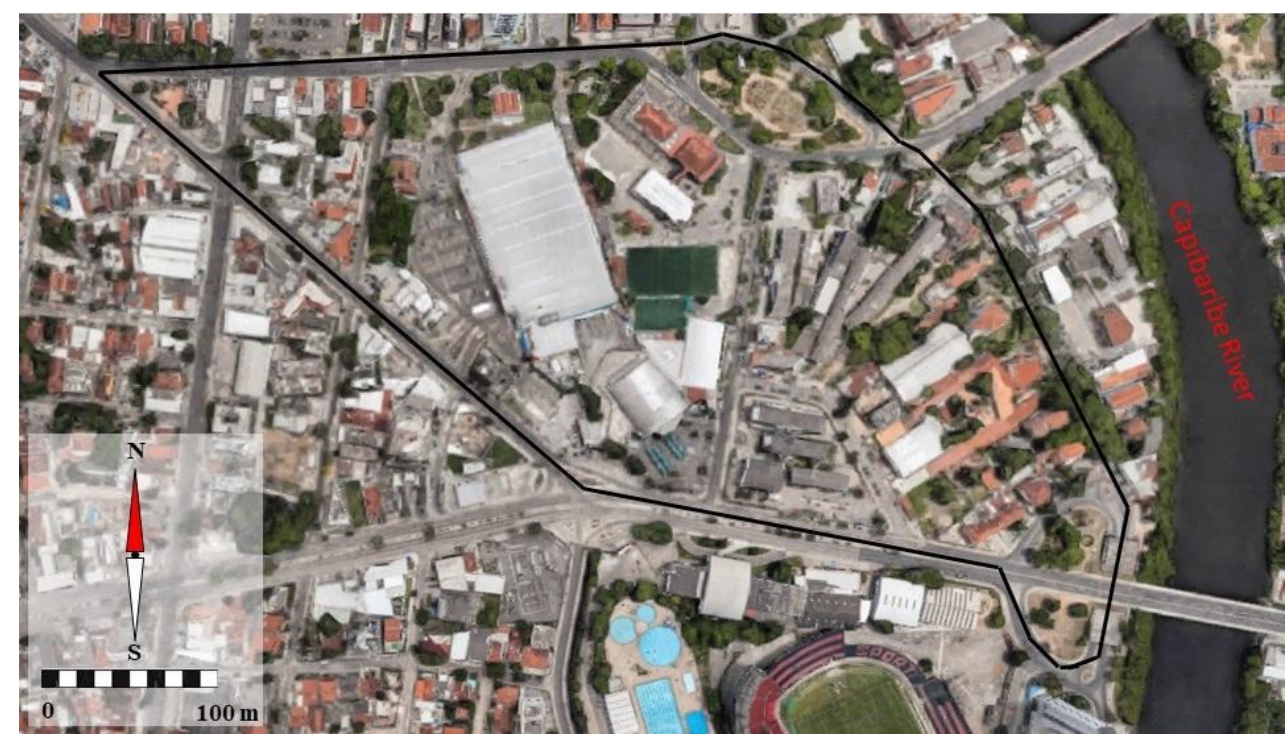

Figure 1. Area demarcated for study.

Most of the city of Recife is composed of flat relief (Silva, 2018). The delimited region varies gradually between 0 and $1 \mathrm{~m}$, with a small slope of $0.0025 \mathrm{~m} . \mathrm{m}^{-1}$. Therefore, the sediments present in the unpaved soil are not leached. 
Hydrus 1-D, used for modeling soil water dynamics, was constructed from a $300 \mathrm{~cm}$ deep layer, subdivided every $10 \mathrm{~cm}$ for contour conditions. The vegetation present at the collection sites was not considered in the simulations, because the crowns of the trees did not cover a large area and the root system was deep with no significant undergrowth along the ground. Urban drainage was also not considered in the simulations, because the absence of maintenance on the network present in this area has resulted in insufficiency of the drainage system.

The simulations were performed using version 4.17 of the HYDRUS-1D model (Simunek et al., 2013), which numerically solves the equation of one-dimensional water flow in porous media having variable saturation (Equation 1).

$\frac{\partial \theta}{\partial t}=\frac{\partial}{\partial z}\left(K \frac{\partial h}{\partial z}\right)$

Where $h$ is the matric potential, $t$ is the time, $z$ is the depth, and $K$ is the hydraulic conductivity of the soil.

In the simulation, the hydraulic model proposed by van Genuchten (1980) was used, where the soil water retention and hydraulic conductivity curves are expressed by Equations 2 and 3:

$$
\begin{aligned}
& \theta(h)=\theta_{r}+\frac{\theta_{s}-\theta_{r}}{\left(1+(\alpha h)^{n}\right)^{1-\frac{1}{n}}} \\
& K(\theta)=K_{s}\left(\frac{\theta-\theta_{s}}{\theta_{s}-\theta_{r}}\right)^{\frac{1}{2}}\left[1-\left(1-\left(\frac{\theta-\theta_{s}}{\theta_{s}-\theta_{r}}\right)^{\frac{1}{1-\frac{1}{n}}}\right)^{1-\frac{1}{n}}\right]^{2}
\end{aligned}
$$

Where $\theta_{r}$ and $\theta_{s}$ are the residual and saturated volumetric humidity, respectively, $\alpha$ and $n$ are the shape parameters, and $K_{s}$ is the saturated hydraulic conductivity. The values of $\theta_{r}, \theta_{s}$, $\alpha$, and $n$, which are required input values for the Hydrus 1D model, were obtained through the use of pedotransfer functions (PTFs), proposed by Barros et al. (2013), and the $K_{s}$ values were estimated using the proposal by Cosby et al. (1984). The values of these parameters are found using Equations 4, 5, 6, 7 and 8, shown below:

$$
\begin{aligned}
& \alpha=10^{0.93-1.60 G} \\
& n=1.53+0.33 A-0.39 G \\
& \theta_{r}=0.13-0.15 A+0.36 G \\
& \theta_{S}=0.55-0.23 A-0.12 G \\
& K_{S}=7.05556 \times 10^{-6} \times 10^{(-0.6+0.0126 A-0.0064 G)}
\end{aligned}
$$

These take into account the contribution of each component of the soil, where $A$ is the sand content $\left(\mathrm{kg} \mathrm{kg}^{-1}\right)$ and $G$ is the clay content $\left(\mathrm{kg} \mathrm{kg}^{-1}\right)$.

The soil granulometry was obtained using the NBR 7181 method (ABNT, 2016). This standard determines that the samples be sieved to separate the fractions of sand (with a diameter greater than or equal to $0.075 \mathrm{~mm}$ ) from the fractions of silt and clay (with diameter smaller than $0.075 \mathrm{~mm}$ ). This finer material must then be subjected to a sedimentation process, thereby obtaining the clay and silt quantities present in each of the 27 samples collected (Density Method).

To carry out the water simulation, the atmospheric parameters of wind speed, maximum and minimum temperatures, insolation time, precipitation, and relative humidity were used as contour conditions. The atmospheric data were obtained from the National Institute of 
Meteorology (INMET) database at the Curado station, where the meteorological station sensors are read and verified by an observer at predefined time intervals.

In order to estimate the daily reference evapotranspiration, the Penman-Monteith model was used, which is described by the FAO and makes use of input parameters such as precipitation, maximum and minimum temperatures, relative humidity, wind speed, and insolation time. In this case, the volume of accumulated precipitation (Figure 2A) was approximately $2264.8 \mathrm{~mm} . \mathrm{m}^{-2}$, with two major rains having values of $81.6 \mathrm{~mm}$ and $73.0 \mathrm{~mm}$, and an average rainfall of $5.72 \mathrm{~mm}$. Over the seven months analyzed, there were 63 days on which no precipitation occurred, with the period between January 1 and March 3 being the longest without any rainfall greater than $10 \mathrm{~mm}$.

The maximum and minimum temperatures (Figure 2B) were at their lowest levels during the months of greatest rainfall, that is, from May to July. It can also be observed that the periods with the greatest amount of sunlight, shown in Figure 2E, are during the months of January and February, which were the least rainy and had the lowest relative humidity (Figure 2D).

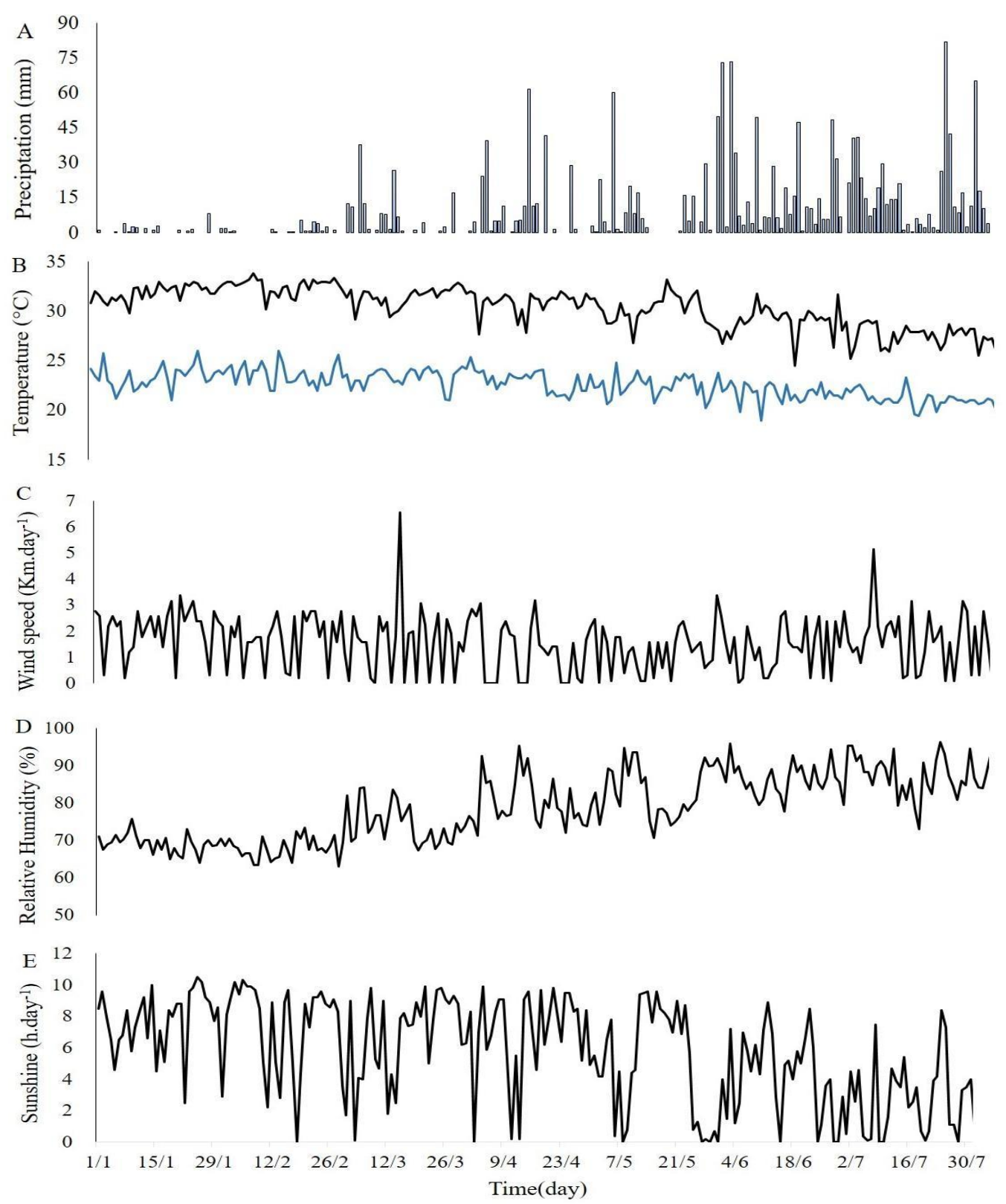

Figure 2. A accumulated rainfall values, $\mathbf{B}$ maximum (black) and minimum (blue) temperature, $\mathbf{C}$ wind speed, $\mathbf{D}$ relative humidity and $\mathbf{E}$ daily sunshine. 


\section{RESULTS AND DISCUSSION}

\subsection{Hydrodynamic Parameters}

Knowing the hydraulic conductivity or the infiltration capacity of the soil is very important because, according to the physical characteristics of each soil type, the infiltration of rainwater will be of different form and intensity, and this will affect the capacity of the soil to favor water percolation to the water table (Souza and Rodrigues, 2014).

According to Giachetti et al. (2000), soils with low or intermediate saturated hydraulic conductivity values may be clayey or silty, while sandy soils usually have high Ks values. The soil studied is characterized as being mostly sandy with a saturated hydraulic conductivity of

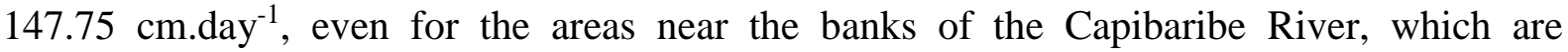
approximately $15 \mathrm{~m}$ away.

Another important factor to be considered in studies such as this is the composition of the soil, since, according to Oliveira et al. (2013), the water infiltration potential depends directly on the sand and clay content. In addition, they also stated that the rate of infiltration of water into clayey soils is usually lower than the rate of infiltration into sandy soils.

The soil studied was composed mainly of sand $(83.82 \%)$ with a small portion of clay $(3.83 \%)$ and the rest being silt (12.35\%). The values of $\alpha=0.0413 \mathrm{~cm}^{-1}, n=1.9446, \theta_{s}=$ $0.3857 \mathrm{~cm}^{3} \mathrm{~cm}^{-3}$, and $\theta_{r}=0.0408 \mathrm{~cm}^{3} \mathrm{~cm}^{-3}$ were obtained from the soil composition and used as necessary input values for the Hydrus 1D model simulation of soil water dynamics.

\subsection{Modeling}

During the period under study, from January to July 2017, the amount of water that infiltrated into the unpaved soil was approximately $355.18 \mathrm{~mm} \cdot \mathrm{m}^{-2}$, with near constant growth at some times of the year. The soil was found to have a high infiltration capacity, corroborating with the study by Coutinho (2011). However, due to the increasing amount of impermeabilized areas inherent to urbanization, which already cover $83 \%$ of the study area, the amount of water that can infiltrate into the soil has gradually diminished.

The rates of evaporation, infiltration, and runoff for the months of January to July 2017 originated from the simulations (Figure 3). In addition, these simulations also showed that, of the $385.02 \mathrm{~mm} . \mathrm{m}^{-2}$ that precipitated onto the $17 \%$ of unpaved soil during this period, 355.18 $\mathrm{mm} . \mathrm{m}^{-2}$ infiltrated and the rest either drained or evaporated, completing the area's water balance and showing the effectiveness of Hydrus-1D in modeling the water balance of the studied area.

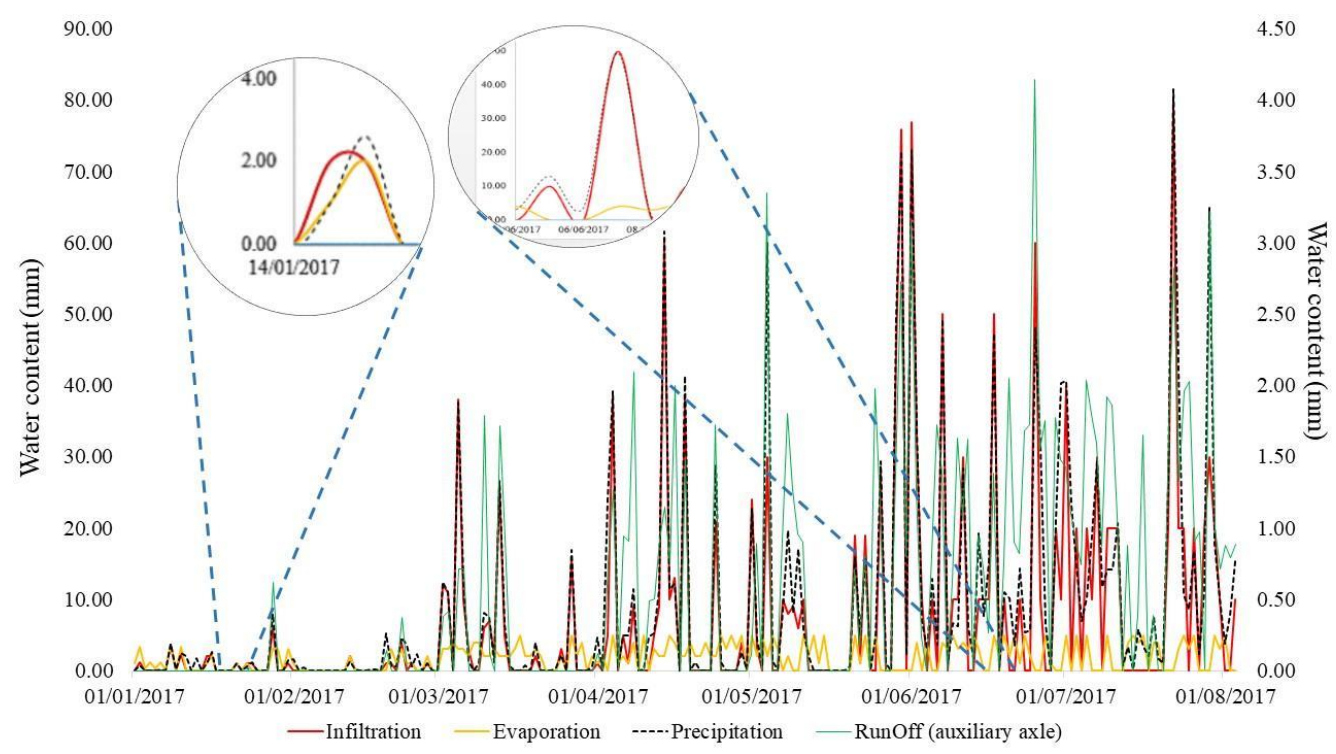

Figure 3. Water balance from January to July 2017 generated using Hydrus-1D.

Rev. Ambient. Água vol. 14 n. 4, e2386 - Taubaté 2019 
By comparing the rates of evaporation, infiltration, runoff and precipitation, it can be seen that, during the drier months of January and February, the evaporation curve (yellow) accompanies the precipitation curve (black). On January 14, for example, the water evaporation levels are consistent with precipitation levels. It is possible to observe that the rate of infiltration for this day is similar to the rates of evaporation and precipitation, but it reflects the accumulation of precipitation from the previous two days (Figure 3).

During the rainiest months, June and July, the infiltration curve (red) accompanies the precipitation curve (black). On June 6, for example, it can be observed that practically everything that infiltrated was related to the rain that fell on that day, while the amount of water that evaporates is related to the amount of water that did not infiltrate during the preceding days. Thus, it is possible to infer that if the paved area were smaller than its current $83 \%$, the locality would not suffer from constant flooding, because the soil present in the Madalena neighborhood allows for high rates of infiltration, agreeing with the study by Souza and Rodrigues (2014), which shows that soils with mostly sandy textures allow water to infiltrate more efficiently.

The month of July had the lowest evaporation rate during the period studied and it presented the highest precipitation values, more than $81 \mathrm{~mm}$, as can be observed in Figure 2A. This is due to the fact that, on the rainiest days, the amount of solar radiation reaching the surface is usually lower, which reduces the amount of evaporation taking place. It also needs to be taken into account that, in the wetter months, the relative humidity is higher, increasing the vapor pressure and reducing evapotranspiration rates. During the drier months of January and February, the highest evaporation rates were observed, approximately $6 \mathrm{~mm}^{\text {day }}{ }^{-1}$, as well as the highest temperatures $\left(36.8^{\circ} \mathrm{C}\right)$ and lowest rainfall rates (Figure $2 \mathrm{~B}$ ), in line with the results obtained by Ismael Filho et al. (2015).

Due to the heavy rainfall in the months of June and July, there is an increase in the amount of runoff because the few permeable areas saturate rapidly. In this case, in addition to rainfall, the presence of the Capibaribe River must be taken into account, which reduces the depth of the water table and consequently decreases the amount of water needed to saturate the permeable areas.

As its saturated hydraulic conductivity $K_{s}$ is $147.75 \mathrm{~cm} \mathrm{day}^{-1}$, the soil present in the Madalena neighborhood should be able to absorb all rainwater without generating significant flooding. However, as only $17 \%$ of the soil present in the locality is permeable, the scenario ends up reversed, with numerous floods occurring throughout the year, before even considering the interaction between the amount of residual water present in the soil and its infiltrability. It can therefore be said that in months where there is greater rainfall, as well as lower evapotranspiration rates and radiation balance, the Madalena neighborhood is susceptible to constant flooding, corroborating the study by Moreira (2014). That author goes even further in his analysis, noting that even following the construction of the Tapacura dam complex to control floods, poor occupation and use of soil in the region has intensified flooding events.

However, before the process of urbanization took place in Recife (or in the Madalena neighborhood), historical records from 1632 already indicated the occurrence of floods in the region (PE-AZ, 2011). The results obtained can be extrapolated to the areas surrounding the Madalena neighborhood, which make up the central zone of Recife, making it possible to explain flooding in other districts of the city, in addition to those in Madalena.

Just as in the Madalena neighborhood, where only $17 \%$ of the soil remains unpaved, other neighborhoods in the city of Recife (and in other large cities) also have few areas favorable to the drainage of rainwater. Many important neighborhoods of the city are therefore susceptible to flooding, especially in the months when the river level is higher and evaporation rates are lower. In addition to hampering access by residents, this flooding also disrupts the flow of through-traffic, considering the important avenues that cut through neighborhoods. 


\section{CONCLUSION}

The soil present in the unpaved areas has a high water infiltrability capacity, since the data obtained through the simulations show that $355.18 \mathrm{~mm} . \mathrm{m}^{-2}$ of the $385.02 \mathrm{~mm} . \mathrm{m}^{-2}$ total precipitation was infiltrated, or $92.25 \%$. This was expected due to the high sand content in its composition, containing $83.82 \%$ sand, $12.35 \%$ silt, and $3.83 \%$ clay. The remaining amount of water from this total precipitation either formed surface runoff or evaporated.

Flooding is more frequent during the months of June and July, which have the highest pluviometric indexes and the lowest sunshine indexes. Like the Madalena neighborhood, other localities also suffer from the same flooding problem inherent where there are high amounts of impermeable soil. If the impermeable area were not so high, $83 \%$, it would be difficult for the study area to suffer constant flooding, because the natural soil below the impermeable portion is sandy.

Compensatory urban drainage techniques, such as permeable pavement, infiltration trenches, rain gardens, green roofs, and retention and detention basins, have been proposed to assist the existing drainage system in minimizing flooding and in large urban centers. Some of these techniques are already being used in Recife, such as green roofs, which are mandatory and governed by Municipal Law 18.112/2015 (Recife, 2015).

\section{REFERENCES}

ABNT. NBR - 7181: Solo - Análise granulométrica. Rio de Janeiro, 2016. 16p.

BARROS, A. H. C.; LIER, Q. J. V.; MAIA, A. H. N.; SCARPARE, F. V. Pedotransfer Functions to Estimate Water Retention Parameters of Soils in Northeastern Brazil; Revista Brasileira de Ciências do Solo, v. 37, n. 2, p. 379-391, 2013. http://dx.doi.org/10.1590/S0100-06832013000200009

CARVALHO, W. M.; ALMEIDA, J. C. Patologias de edifícios históricos tombados estudo de caso: Convento das Mercês. In: CONFERÊNCIA SOBRE PATOLOGIA E RABILITAÇÃO DE EDIFÍCIOS, 6., 2018, Rio de janeiro. Proceedings[...]Rio de Janeiro: PATORREB: POLI-UERJ, 2018.

CAVALCANTI, H. F. Consequências da urbanização desordenada em área de nascente. Revista Didática Sistêmica, v .15, n. 1, 2013.

CORTE, A. C. D. Balanço hídrico em bacia urbana. 2015. 88p. Dissertation (Master's) Centro de Tecnologia - Universidade Federal de Santa Maria, Santa Maria, 2015.

COSBY, B. J.; HORNBERGER, G. M.; CLAPP, R. B.; GINN, T. R. A statistical exploration of the relationship of soil moisture characteristics to the physical properties of soils. Water Resources Research, v. 20, n. 6, p. 682-690, 1984.

COUTINHO, P. A. Pavimento permeável como técnica compensatória na drenagem urbana da cidade do Recife. 2011. 153 p. Dissertation (Master's) - Federal University of Pernambuco, Recife, 2011.

GENUCHTEN, M. T. Van. A closed-form equation for predicting the hydraulic conductivity of unsaturated soils. Soil Science Society of America Journal, v. 44, n. 3, p. 892-898, 1980. https://dx.doi.org/10.2136/sssaj1980.03615995004400050002x 
GIACHETTI, H. L.; FERREIRA, C. V.; LOBO, A. S.; MARQUES, M. E. M. A condutividade hidráulica de um solo arenoso determinada a partir de ensaios de campo e de laboratório. In: CONGRESO INTERAMERICANO DE INGENIERÍA SANITARIA Y AMBIENTAL, 27., Porto Alegre. Proceedings[...] Porto Alegre: ABES, 2000. p. 1-10.

ISMAEL FILHO, A.; BORGES, P. de F.; ARAÚJO, L. de S.; PEREIRA, A. R.; LIMA, E. M. de; SILVA, L. dos S.; SANTOS JUNIOR, C. V. dos. Influência das variáveis climáticas sobre a evapotranspiração. Gaia Scientia, v. 9, n.1, p. 62-66, 2015.

MARTINEZ, M. A.; SILVA, J. B. G. Modelagem do movimento de sais no solo. In: GHEYI, H. R.; DIAS, N. S.; LACERDA, C. F. DE. (Org.). Manejo de salinidade na agricultura: estudos básicos e aplicados. 1. Ed. Fortaleza: INCTsal, 2010. v. 1, p. 93-113.

MOREIRA, M. F. “Tapacurá estourou!": a vulnerabilidade da cidade anfíbia (Recife-PE) aos episódios de inundações e o bairro da Madalena. 2014. Thesis (Doctorate in Human Sciences) - Federal University of Santa Catarina, Florianópolis, 2014.

MUJOVO, M. J. N. Simulação de fluxo vertical em trincheiras de infiltração urbana. Dissertation (Master's) - University Federal de Santa Catarina, Florianópolis, 2014.

OLIVEIRA, N. S.; BARREIRA, R. Q.; BESSA, M. S. C.; PONTES, J. R. V.; SANTOS, C. L. Infiltração de água no solo arenoso e argiloso utilizando o método de anel simples no município de Conceição do Araguaia - PA. In: CONGRESSO BRASILEIRO DE GESTÃO AMBIENTAL: gestão ambiental e sustentabilidade, 4., 2013, Salvador. Proceedings[...] Salvador: IBEAS, 2013.

PE-AZ. Enchentes. $2011 . \quad$ Recife, Available at: http://www.peaz.com.br/index.php?option=com_content\&view=article\&id=1400:enche ntes \&catid =15\&Itemid=173. Accessed on: 26 Dec. 2018.

RECIFE. Lei $\mathrm{n}^{\mathrm{o}}$ 18.112/2015. Dispõe sobre a melhoria da qualidade ambiental das edificações por meio da obrigatoriedade de instalação do "telhado verde", e construção de reservatórios de acúmulo ou de retardo do escoamento das águas pluviais para a rede de drenagem e dá outras providências. Diário Oficial, Recife, 12 jan. 2015.

SILVA, A. C. Modelagem hidrológica-hidráulica para atenuação de alagamentos no entorno da Escola Politécnica de Pernambuco. 2018. Dissertation (Master's) University of Pernambuco, 2018.

SIMU゚NEK, J.; SEJNA, M.; SAITO, H.; SAKAI, M.; van GENUCHTEN, M. Th. The HYDRUS-1D Software Package for Simulating the One-Dimensional Movement of Water, Heat, and Multiple Solutes in Variably-Saturated Media. Riverside: University of California Riverside, 2013. v. 1, p. 1-308.

SOARES, W. de A. Impact of spineless cactus cultivation (O. ficus-indica) on the thermal characteristics of soil. Revista Ambiente \& Água, v. 13, n. 1, p. 1-13. 2018. http://dx.doi.org/10.4136/ambi-agua.2148

SOUZA, F. A.; RODRIGUES, S. C. Estimativa de recarga do lençol freático em solos sobre granito e gabros alcalinos na alta bacia do rio dos Boise m Iporá - GO. Ambiência, v. 10, n. 2, p. 499-463, 2014. https://dx.doi.org/10.5216/revgeoamb.v0i25.35332

TUCCI, C. E. M. Gerenciamento integrado das inundações urbanas no Brasil. Revista de Gestão de Água da América Latina, v. 1, n. 1, p. 59-73, 2004. http://dx.doi.org/10.21168/rega.v1n1.p59-73 
TUCCI, C. E. M. Hidrologia: ciência e aplicação. Porto Alegre, ABRH, 2007. 944p.

ZENG, W.; LEI, G.; ZHA, Y.; FANG, Y.; WU, J.; HUANG, J. Sensitivity and uncertainty analysis of the HYDRUS-1D model for root water uptake in saline soils. Crop and Pasture Science. v. 69, n. 2, p. 163-173, 2018. https://dx.doi.org/10.1071/CP17020 